\title{
Job insecurity, extrinsic and intrinsic job satisfaction and affective organisational commitment of maintenance workers in a parastatal
}

\author{
J.H. Buitendach* \\ WorkWell: Research Unit for People, Policy \& Performance, North-West University, \\ School of Behavioural Sciences, Vaal Triangle Campus, Republic of South Africa \\ bpkjhb@puknet.puk.ac.za \\ H. De Witte \\ Department of Psychology, University of Leuven, Belgium
}

Received January 2005

\begin{abstract}
The objective of this study was to assess the relationship between job insecurity, job satisfaction and affective organisational commitment of maintenance workers $(N=178)$ in a parastatal in Gauteng. A crosssectional design was used. Stratified random samples of maintenance workers $(N=178)$ were taken. The Job Insecurity Inventory, Minnesota Job Satisfaction Questionnaire and Organisational Commitment Questionnaire were used as measuring instruments. The results revealed small but significant relationships between job insecurity and extrinsic job satisfaction and job insecurity and affective organisational commitment. Job satisfaction was found to mediate the relationship between job insecurity and affective organisational commitment.
\end{abstract}

*To whom all correspondence should be addressed.

\section{Introduction}

Since the late 1970s economic recessions, industrial restructuring, technological changes and intensified global competition have dramatically changed the nature of work (Howard, 1995). According to Hartley, Jacobson, Klandermans and Van Vuuren (1991), changes such as economic uncertainty, global competition and an increase in mergers and acquisitions in the past decade have forced organisations to improve organisational effectiveness and streamline operations through downsizing, outsourcing and restructuring. These actions are associated with large-scale workforce reductions. For many employees these changes in working life cause feelings of insecurity regarding the nature and future existence of their jobs.

Literature suggests that perceptions of job insecurity might have detrimental consequences for employee attitudes (Ashford, Lee, \& Bobko, 1989; Rosenblatt, Talmud, \& Ruvio, 1999), increase in job dissatisfaction (Davy, Kinicki, \& Scheck, 1997), an increase in negative health outcomes (Hellgren \& Sverke, 2003; Mohren, Swaen, Van Amelsvoort, Borm, \& Galama, 2003) and higher reports of psychological distress (Dekker \& Schaufeli, 1995; Probst, 2000). In addition, employees with perceptions of low job security are more likely to engage in work withdrawal behaviour (Q'Quin, 1998) and report lower organisational commitment (Preuss \& Lautsch, 2003). This often leads to employee turnover (Ashford et al., 1989) and decreased safety motivation and compliance, which in turn lead to higher levels of workplace injuries and accidents (Probst \&
Brubaker, 2001), organisational viability (Kets, De Vries \& Balazs, 1997), as well as reduced well-being (De Witte, 1999; Kinnunen, Mauno, Nätti, \& Happonen, 2000; Mohr, 2000).

South African companies are being exposed more than ever to the effects of the world economy, technological advancement and tough international competition. Tremendous pressure is placed on organisations to improve their performance and to become increasingly competitive. In such a competitive environment, the first fundamental consideration for most organisations is their profitability. In order for them to gain a competitive advantage, companies need to determine sources of cost-savings. According to Marais and Schepers (1996), such sources include economies of scale, technology, access to raw materials and salaries and wages, the latter usually being the largest, immediate source of cost-savings.

\section{Job insecurity}

Job insecurity has been described in different ways and consensus on the exact definition has not yet been reached (De Witte, 1999; Mauno \& Kinnunen, 2000). According to the global view, job insecurity relates to people in their work context, who fear they might lose their jobs and become unemployed (De Witte, 1999). Hartley et al. (1991) define job insecurity as a discrepancy between the levels of security people experience and the level they might prefer. Hui and Lee (2000) describe job insecurity as the lack of 
control to maintain desired continuity in a threatened job situation.

Van Vuuren (1990) describes job insecurity as the concern felt by a person for the continued existence of his/her job and identifies three components which are central to job insecurity. The first component refers to a subjective experience or perception; the second to uncertainty about the future and the third component includes doubts concerning the continuation of the job as such. In a multidimensional view of job insecurity, the concept of job insecurity not only refers to the amount of uncertainty employees feel about their job continuity, but also about the permanence of certain dimensions of the job, such as organisational benefits and promotional opportunities (Rosenblatt \& Ruvio, 1996).

People also develop affective and attitudinal attachments towards their workplace over time, which show up as high levels of commitment, satisfaction, and trust (Allen \& Meyer, 1990; Mowday, Porter \& Steers, 1979). Feelings of job insecurity may threaten these basic attachments, such as commitment, satisfaction and trust (Rosenblatt \& Ruvio, 1996). A downward spiral is created, where productivity decreases and absenteeism increases, which might result in the competitive strength of the company being undermined (Hartley et al., 1991).

\section{Job satisfaction}

Job satisfaction is a widely researched topic (Li-Ping Tang \& Talpade, 1999). Yousef (2000) mentions that the reason for this relates to the significant associations of job satisfaction with several variables. For instance, it has a positive association with life satisfaction (Judge, Boudreau \& Bretz, 1994), organisational commitment (Fletcher \& Williams, 1996) and job performance (Babin \& Boles, 1996).

According to Hirschfeld (2000), job satisfaction is the extent to which people like their jobs. Job satisfaction can be described as an affective or emotional reaction to the job, resulting from the incumbent's comparison of actual outcomes with the required outcomes (Cranny, Smith \& Stone; 1992; Hirschfeld, 2000; Locke, 1976). Schneider and Snyder (1975), on the other hand, define job satisfaction as a personal evaluation of conditions present in the job, or outcomes that arise as a result of having a job. Weiss, Dawis, England and Lofquist (1967) explain this comparison further by stating that employees seek to achieve and maintain correspondence with their environment. Correspondence with the environment can be described in terms of the individual fulfilling the requirements of the environment, and the environment fulfilling the requirements of the individual (Cook, Hepworth, Wall \& Warr, 1981). This means that employees will experience job satisfaction if they feel that their individual capacities, experience and values can be utilised in their work environment and that the work environment offers them opportunities and rewards (Dawis, 1992; Roberts \& Roseanne, 1998). Job satisfaction thus has to do with an individual's perceptions and evaluation of his job, and this perception is influenced by the person's unique circumstances such as needs, values and expectations. People will therefore evaluate their jobs on the basis of factors which they regard as being important to them (Sempane, Rieger \& Roodt, 2002). Employees who are satisfied with their jobs are likely to be better ambassadors for the organisation and show more organisational commitment (Agho, Price \& Mueller, 1992).

Locke (1976) found that in order for researchers to understand job attitudes; they need to understand job dimensions which are complex and interrelated in nature. He mentions the common aspects of job satisfaction such as 'work, pay, promotions, recognition, benefits, working conditions, supervision, co-workers, company and management' (Locke, 1976: 1302). Later research has shown that these different aspects can be arranged according to two dimensions: an intrinsic versus an extrinsic one (Weiss, Dawis, England \& Lofquist, 1967; Spector, 1997; Hirschfeld, 2000). Extrinsic satisfaction refers to satisfaction with aspects that have little to do with the job tasks or content of the work itself, such as pay, working conditions and co-workers. Intrinsic satisfaction refers to the job tasks themselves (e.g. variety, skill utilisation, autonomy).

Since job satisfaction involves employees' emotional feelings, it has major consequences on their lives. Locke (1976:1311) describes the most common consequences of job satisfaction in terms of its effects on the physical health, longevity; mental health, and the impact it has on interaction between employees and the feelings of employees toward their jobs and social lives. Coster (1992) also supports the fact that work can have an important effect on the total quality of life of the employee, behaviour like absenteeism, complaints and grievances, frequent labour unrest and termination of employment (Locke, 1976; Visser, Breed \& Van Breda, 1997).

\section{Organisational commitment}

The topic of organisational commitment has received a great deal of interest in the past decade and numerous studies have been directed at determining its causal antecedents (DeCotiis \& Summers, 1987; Michaels, 1994; Russ \& McNeilly, 1993). Kampfer, Boshoff and Venter (1994) point out that an abundance of research has been conducted on the relationship between commitment and various hypothesised consequences of commitment.

Commitment, which is considered to be a dependent variable in this study, has occupied a central place in organisational research and has been defined as the relative strength of an individual's identification with and involvement in a particular organisation (Mowday, Porter \& Steers, 1979). Bagraim (2003) views this identification as a psychological bond between employees and their employing organisation.

Over the past decade, the dimensionality of the commitment construct has enjoyed careful examination (Pretorius, 1993; Kampfer, Boshoff \& Venter, 1994; Boshoff \& Mells, 1995; Lok \& Crawford, 2001; Bagraim, 2003) and it is now widely accepted that organisational commitment is a multidimensional construct (Meyer \& Allen, 1997). Allen and 
Meyer (1990) propose that there are three components of organisational commitment, namely affective, continuous and normative commitment. As defined by these authors, the affective component of organisational commitment refers to the employee's emotional attachment to, identification with and involvement in the organisation. The continuance component refers to the commitment based on the costs that the employee associates with leaving the organisation. The normative component refers to the employee's feeling of obligation to remain with the organisation. Evidence supporting the distinct nature of these three components has been presented by a number of authors (Durham, Grube \& Castaneda, 1994).

Although organisational commitment has been conceptualised as a multi-dimensional construct, it is the measures based on the attitudinal approach which in previous studies have most frequently been validated and used (O’Reilly \& Chatman, 1986; Price \& Muller, 1981; Somers, 1993; Morrison, 1994), as well as revised (Meyer, Allen \& Smith, 1993; Allen \& Meyer, 1996). Research however shows that one of the three dimensions is more relevant than the two others (for an overview: Allen \& Meyer, 1996). First of all, the measurement of affective organisational commitment is more reliable than the measurement of the other components. Even more important is the finding that affective organisational commitment is the most important explanatory variable of the three components: the affective dimension consistently explains more variance in outcome variables than the two other components (Allen \& Meyer, 1996). As a consequence, many researchers restrict the measurement of organisational commitment to affective commitment, leaving the two other components aside. In this article, we will follow this tradition by only focussing on affective commitment as core concept of organisational commitment.

Job satisfaction and organisational commitment are not unrelated. The empirical results reported by Summers and DeCotiis (1987); and Mowday, Porter and Steers (1982) even showed that job satisfaction exerted a fairly strong positive influence on organisational commitment.

\section{Aims of the study}

The primary aim of this study was to investigate the relationship between job insecurity, job satisfaction and organisational commitment of maintenance workers in a parastatal, and also to examine whether job insecurity can predict job satisfaction and organisational commitment. Previous research (Sverke \& Hellgren, 2002; Hellgren, Sverke \& Isaksson, 1999; Yousef, 1997) found that the perceived level of job insecurity predicts job satisfaction and organisational commitment. In analysing these relationships, some caution is warranted, however. The three core variables of this research (job insecurity, job satisfaction and organisational commitment) are all related to background characteristics such as age, gender and occupational position (see e.g. Spector, 1997; Meyer \& Allen, 1997; Näswall \& De Witte, 2003). This means that the relationships with background characteristics should be kept under control when examining the relationships between our core concepts.
Based on our literature review, we can formulate the following hypotheses.

Hypothesis 1a: Job insecurity will be associated with job dissatisfaction, after controlling for background characteristics: a higher score for job insecurity will be associated with a lower score for job satisfaction.

The literature on job satisfaction reveals that one can distinguish two dimensions: an intrinsic versus an extrinsic one. We can reformulate hypothesis 1a regarding both components.

Hypothesis 1b: Job insecurity will be associated with extrinsic job dissatisfaction, after controlling for background characteristics: a higher score for job insecurity will be associated with a lower score for extrinsic job satisfaction.

Hypothesis 1c: Job insecurity will be associated with intrinsic job dissatisfaction, after controlling for background characteristics: a higher score for job insecurity will be associated with a lower score for intrinsic job satisfaction. The reason for differentiating between intrinsic and extrinsic job satisfaction is that job satisfaction is conceptualised as a two factor construct (Hirscfeld, 2000).

The test of the differential impact of job insecurity on both components of job satisfaction seems to be ignored in the literature. The distinction between both components is an interesting one, however, since job insecurity refers to the extrinsic dimension of the job (contractual security or 'steady employment'). By also analysing its association with intrinsic job insecurity, we test the strength of the impact of job insecurity on workers. If job insecurity has an important impact on well-being (as suggested in literature, e.g. Mauno \& Kinnunen, 1999; Sverke, et al., 2004), then we can expect that it will also affect the satisfaction of workers with the content of their work.

Hypothesis 2: Job insecurity will be negatively associated with affective organisational commitment, after controlling for background characteristics: a higher score for job insecurity will be associated with a lower score for affective organisational commitment.

In this article, both job satisfaction and (affective) organisational commitment are analysed. This allows testing a last hypothesis regarding the impact of job insecurity on both concepts simultaneously. In our literature review, we suggested that job satisfaction influences organisational commitment. Taken together, this suggests that job insecurity affects job satisfaction, and that job satisfaction in turn affects organisational commitment. We can test the hypothesis that job satisfaction mediates that association between job insecurity and affective organisational commitment.

Hypothesis 3: Job satisfaction mediates that association between job insecurity and affective organisational commitment. 


\section{Method}

\section{Research design}

A cross-sectional survey design was used to describe the information on the population collected at that time. This design (Shaughnessy \& Zechmeister, 1997) can also be used to evaluate interrelationships among variables within a population and is ideal to describe and predict functions associated with correlative research.

\section{Participants}

The study population consists of maintenance workers working in a parastatal in the Gauteng Province $(N=178)$. The study population includes representatives from sections such as electrical $(N=34)$, mechanical $(N=97)$, instrumentation $(N=25)$, contract management $(N=7)$, project management $(N=7)$ and training $(N=9)$ within the maintenance department. Participants are also graded at various levels on the Paterson Grading Scale, including artisan helpers (unskilled) $(N=18)$, general workers (semiskilled) $(N=32)$, artisans (skilled) $(N=79)$, technicians and team leaders (semi-professionals) $(N=34)$, as well as managers and other professional staff $(N=5)$. A total of $5 \%$ of the participants were female, $95 \%$ were male. The mean age of the participants was 36,5 .

\section{Measuring instruments}

The Job Insecurity Inventory (JII) (De Witte, 2000) was used to measure the levels of perceived job insecurity. The JII consists of 11 items, measuring cognitive (e.g. 'Chances are I will soon lose my job') and affective (e.g. 'I fear I will lose my job') aspects of job insecurity. The items are arranged along a Likert-type scale with 1 = strongly agree, 3 = unsure, and 5 strongly disagree. De Witte (2000) reported an alpha coefficient of 0.92 for the total scale.

The Minnesota Satisfaction Questionnaire's (MSQ) (Weiss et al., 1967) indicates how satisfied or dissatisfied respondents are with their jobs by asking respondents to rate themselves on 20 questions by using a five-point scale ( $1=$ very dissatisfied to 5 = very satisfied). The revised MSQ form measures intrinsic job satisfaction and extrinsic job satisfaction, using questions like: 'The chance to be "somebody" in the community' (intrinsic), 'The chance to do something that makes use of my abilities' (intrinsic), 'The way my supervisor handles his/her workers' (extrinsic), and 'The working conditions' (extrinsic). Hirschfeld (2000) found that a two-factor model (intrinsic and extrinsic job satisfaction) is superior to a one-factor model (total job satisfaction). Alpha coefficients were found to be ranging from 0,87 to 0,95 , which support the internal consistency of the scale (Hirschfeld, 2000; Lam, Baum \& Pine, 1998).

The Organisational Commitment Questionnaire (OCQ) (Meyer, Allen \& Smith, 1993) was used to measure the affective organisational commitment of the participants. This measure consists of 8 items. Inter-correlations between populations were found to be consistent above 0,90 (Allen \& Meyer, 1990). The internal consistency for this subscale of the questionnaire has been confirmed at the 0,80 level (Suliman \& Iles, 2000).

In order to control for background characteristics, questions were asked on gender ( 1 = male, 2 = female), race $(1=$ black, 2 = white), age and professional category (a reduction of the Patterson job grading system, ranging from 1 ('professional') to 5 ('unskilled blue collar worker').

\section{Data analysis}

The data analysis was carried out with the help of the SAS programme (SAS-Institute, 2000). Cronbach alpha coefficients $(\alpha)$ were used to assess the internal consistency of the measuring instruments (Clark \& Watson, 1995). Descriptive statistics (e.g. means, standard deviations, skewness and kurtosis) were used to analyse the data. Pearson product-momentum correlation coefficients were used to specify the relationship between the variables. In cases where the distribution of the scores was skew, Spearman correlation coefficients were computed. Multiple regression analysis (ordinary least squares) was used to test our hypotheses. These analyses were performed in two steps. In the first step, the four background characteristics were introduced. In the second step, job insecurity was added to these four variables, in order to test its additional explanatory power. A test of the change in $\mathrm{R}^{2}$ indicates whether job insecurity adds to the explanation of the dependent variable after controlling for the background characteristics. The level of significance was set at $p<0,05$. Steyn (2002) criticises the sole uses of statistical significance testing and recommends that effect sizes be established to determine the importance of a statistically significance relationship. While the use of effect sizes are encouraged by the American Psychological Association (APA) in their publication manual (APA, 2002) most of these measures are seldom found in published reports (Kirk, 1996; Steyn, 2002). Therefore, effect sizes were computed to assess the practical significance of relationships in this study. A cut-off point of 0,30 , which represents a medium effect (Cohen, 1988; Steyn, 2002), was set for the practical significance of correlation coefficients.

\section{Results}

Descriptive statistics and Cronbach alpha coefficients of the JII, MSQ, and OCQ for maintenance workers in a parastatal are reported in Table 1.

Table 1 shows that acceptable Cronbach alpha coefficients were obtained for all subscales, varying from 0,65 to 0,88 (see Nunally \& Bernstein, 1994). Scores on all the dimensions seem to be distributed normally, because the skewness and kurtosis are within the guidelines of lower -2 or higher than +2 as set by Tabachnick and Fidell (2001).

Factor analysis was used on all the measuring instruments to assess their unidimensionality. 10 of the 11 items of the JII could be used to compute a reliable total scale for job insecurity (alpha $=0,84$ ). The factor analysis of the MSQ confirmed that there are two dimensions, namely intrinsic satisfaction and extrinsic satisfaction. Besides these two scales, also a total job satisfaction scale was computed. One 
item was excluded from the total and extrinsic scale, however, in order to avoid contamination (e.g. satisfaction with 'The way my job provides for steady employment'). A moderately reliable scale for affective organisational commitment could be computed with three items only $($ alpha $=0,65)$.

The correlation coefficients between the JII, the total MSQ, its two dimensions, and the affective OCQ of maintenance workers in a parastatal $(N=178)$ are reported in Table 2.

As indicated by Table 2, no practically significant relationship could be found between job insecurity and the other variables. Table 2 does not show practically significant relationships between affective organisational commitment and job satisfaction (both dimensions as well as the total scale). Both concepts, however, show a statistically significant correlation, suggesting that higher levels of job satisfaction will result in higher levels of affective commitment to the organisation. As expected, the two dimensions of job satisfaction also correlate with each other (a statistically and practically significant relationship).

To test our hypotheses, a series of multiple regression analyses were performed. Table 3 presents the results of the multiple regression analysis with (the various measures of) job satisfaction as the dependent variable.

Table 1: Descriptive statistics and Cronbach Alpha coefficients of the various measurements for maintenance workers in a parastatal

\begin{tabular}{cccccccc}
\hline Scale & $\begin{array}{c}\text { Number of } \\
\text { items }\end{array}$ & N & Mean & SD & Skewness & Kurtosis & $\begin{array}{c}\text { Alpha } \\
\text { coefficients }\end{array}$ \\
\hline Job Insecurity (JII) & 10 & 177 & 2,51 & 0,83 & 0,11 & $-0,47$ & 0,84 \\
Job satisfaction (total MSQ) & 19 & 169 & 3,47 & 0,67 & $-0,23$ & $-0,36$ & 0,88 \\
Extrinsic Job Satisfaction & 8 & 174 & 3,17 & 0,87 & $-0,19$ & $-0,40$ & 0,84 \\
Intrinsic Job Satisfaction & 7 & 174 & 3,72 & 0,70 & $-0,25$ & $-0,25$ & 0,74 \\
Affective organisational commitment (OCQ) & 3 & 177 & 3,10 & 0,98 & 0,26 & $-0,79$ & 0,65 \\
\hline
\end{tabular}

Table 2: Pearson correlation coefficients between job insecurity (JII), job satisfaction (MSQ) and affective organisational commitment (OCQ)

\begin{tabular}{l|l|l|c|c|c}
\hline \multicolumn{1}{c|}{ Scale } & JII Total & MSQ Total & MSQ Extrinsic & MSQ Intrinsic & OCQ Affective \\
\hline JII Total & 1,00 & & & & \\
\hline MSQ Total & $-0,16^{*}$ & 1,00 & - & - & - \\
\hline MSQ Extrinsic & $-0,13$ & $0,88^{* * * \dagger \dagger}$ & 1,00 & - & - \\
\hline MSQ Intrinsic & $-0,15^{*}$ & $0,76^{* * * \dagger \dagger}$ & $0,41^{* * * \dagger}$ & 1,00 & - \\
\hline OCQ Affective & $-0,25^{* *}$ & $0,26^{* *}$ & $0,28^{* * *}$ & $0,15^{*}$ & 1,00 \\
\hline
\end{tabular}

* Statistically significant $p \leq 0.05$; ** Statistically significant $p \leq 0.01 ; * * *$ Statistically significant $p \leq 0.001$

$\dagger$ Correlations are practically significant $r \geq 0.30$ (medium effect); †† Correlations are practically significant $r \geq 0.50$ (large effect)

Table 3: Results of a regression analysis with job satisfaction (MSQ) as dependent variable, and background characteristics and job insecurity as predictors (Bêta-coefficients)

\begin{tabular}{c|c|c|c|c|c|c}
\hline \multirow{2}{*}{ Predictors } & \multicolumn{2}{|c|}{ MSQ Total } & \multicolumn{2}{c|}{ MSQ Extrinsic } & \multicolumn{2}{c}{ MSQ Intrinsic } \\
\cline { 2 - 7 } & Step 1 & Step 2 & Step 1 & Step 2 & Step 1 & Step 2 \\
\hline Gender & $-0,07$ & $-0,06$ & $-0,00$ & $-0,00$ & $-0,08$ & $-0,08$ \\
Race & 0,06 & 0,04 & $-0,07$ & $-0,09$ & $0,18^{*}$ & $0,17^{*}$ \\
Age & 0,16 & 0,14 & 0,12 & 0,12 & 0,11 & 0,11 \\
Professional category & 0,03 & 0,11 & 0,02 & 0,10 & $-0,00$ & 0,05 \\
Job Insecurity & $/$ & $-0,21^{*}$ & $/$ & $-0,21^{*}$ & $/$ & $-0,12$ \\
\hline $\mathrm{R}$ & 0,19 & 0,27 & 0,16 & 0,25 & 0,23 & 0,25 \\
$\mathrm{R}^{2}$ & 0,04 &, 07 & 0,02 & 0,06 & 0,05 & 0,06 \\
F-value & 1,44 & $2,35^{*}$ & 1,02 & $2,07^{*}$ & 2,14 & 2,14 \\
Degrees of freedom & $(4,151)$ & $(5,150)$ & $(4,156)$ & $(5,155)$ & $(4,156)$ & $(5,155)$ \\
\hline Change in R $\mathrm{R}^{2}$ & $/$ & $0,04^{*}$ & $/$ & $0,04^{*}$ & $/$ & 0,01 \\
\hline
\end{tabular}

*Statistically significant $p \leq 0,05$; ** Statistically significant $p \leq 0,01$; *** Statistically significant $p \leq 0,001$ 
We first of all wanted to test whether job insecurity is associated with (total) job dissatisfaction, after controlling for background characteristics (hypothesis 1a). The results in Table 3 show that this hypothesis is corroborated: a higher score for job insecurity is indeed associated with a lower score on the total job satisfaction scale (Bêta $=-, 21, p$ $<, 05)$. The addition of job insecurity in step 2 also increased the explanatory power of the analysis (the change in $\mathrm{R}^{2}$ is ,04, $p<, 05$ ), even though the total amount of variance explained is rather low (only 7\%).

Hypothesis $1 \mathrm{~b}$ and $1 \mathrm{c}$ deal with the differential impact of job insecurity on both components of job satisfaction. Hypothesis 1b stated that job insecurity will be associated with extrinsic job dissatisfaction, and hypothesis 1c that job insecurity will be associated with intrinsic job dissatisfaction. The results in Table 3 corroborate hypothesis $1 \mathrm{~b}$, but not hypothesis 1c. After controlling for background characteristics, a higher level of job insecurity is associated with a lower level of extrinsic job satisfaction (Bêta $=-, 21, p$ $<, 05)$. Including job insecurity increases the explanatory power of the analysis (the change in $\mathrm{R}^{2}$ is $, 04, p<, 05$ ), even though the total amount of variance explained is rather low in this analysis too (only 6\%). The analysis with intrinsic job satisfaction as dependent variable, fails to show a significant effect of job insecurity (Bêta = -,12, n.s.; the change in $\mathrm{R}^{2}$ is ,01, n.s.). We can conclude that the effect of job insecurity on the total scale of job satisfaction is due to the extrinsic dimension of job satisfaction only.

Table 4 presents the results of the multiple regression analysis with organisational commitment as the dependent variable.

Table 4: Results of a regression analysis with affective organisational commitment as dependent variable, and background characteristics and job insecurity as predictors (Bêta-coefficients)

\begin{tabular}{|c|c|c|}
\hline Predictors & & \\
\hline Gender & $-0,01$ & $-0,01$ \\
\hline Race & $-0,14$ & $-0,16^{*}$ \\
\hline Age & $0,27 * *$ & $0,26 * *$ \\
\hline Professional category & $-0,40 * * *$ & $-0,32 * *$ \\
\hline Job Insecurity & I & $-0,20 *$ \\
\hline $\mathrm{R}$ & 0,36 & 0,40 \\
\hline $\mathrm{R}^{2}$ & 0,13 & 0,16 \\
\hline F-value & $5,80 * * *$ & $6,04 * * *$ \\
\hline Degrees of freedom & $(4,160)$ & $(5,159)$ \\
\hline Change in $\mathrm{R}^{2}$ & 1 & $0,03 *$ \\
\hline
\end{tabular}

Hypothesis 2 states that job insecurity will be negatively associated with affective organisational commitment, after controlling for background characteristics. The results in Table 4 corroborate this hypothesis: a higher score for job insecurity is indeed associated with a lower score for affective organisational commitment (Bêta $=-, 20, p<, 05$ ). The addition of job insecurity in step 2 again increased the explanatory power of the analysis (the change in $\mathrm{R}^{2}$ is $, 03, p$ $<, 05)$. The amount of variance in affective organisational commitment explained by all variables included in the analysis, is less moderate than in the previous analyses $(16 \%)$.

In order to test hypothesis 3, stating that job satisfaction will mediate the association between job insecurity and affective organisational commitment, a last series of regression analyses was performed. Baron and Kenny (1986) recommend three steps in order to test for mediation. According to these authors, bêta coefficients of different regression equations must be compared. First, the mediator should be predicted by the independent variable. Second, the dependent variable should be predicted by the mediator and the independent variable. Last, the dependent variable should be regressed on the independent variable, controlling for the mediator. If all steps prove significant, perfect mediation holds when, controlling for the mediator, the independent variable does not predict the dependent variable. The dependent variable in hypothesis 3 is organisational commitment, the independent variable is job insecurity and the mediator is job satisfaction. The results in Table 3 already showed that the mediator (job satisfaction) can be predicted by the independent variable (job insecurity), suggesting that there is evidence for the first step of Baron and Kenny's procedure. The results in Table 4 showed that the dependent variable (affective organisational commitment) can be predicted by the independent variable (job insecurity) too (part of the second step of Baron \& Kenny's procedure). In order to test the assumption that the dependent variable (affective organisational commitment) can be predicted by the mediator (job satisfaction), a separate regression analysis was performed (see Table 5).

Table 5: Results of a regression analysis with affective organisational commitment as dependent variable, and background characteristics and job satisfaction as predictors (Bêta-coefficients)

\begin{tabular}{|c|c|c|}
\hline Predictors & & \\
\hline Gender & $-0,05$ & $-0,03$ \\
\hline Race & $-0,15$ & $-0,17^{*}$ \\
\hline Age & $0,29 * * *$ & $0,26 * *$ \\
\hline Professional category & $-0,41 * * *$ & $-0,42 * * *$ \\
\hline Job satisfaction & l & $0,25 * *$ \\
\hline $\mathrm{R}$ & 0,38 & 0,46 \\
\hline $\mathrm{R}^{2}$ & 0,15 & 0,21 \\
\hline F-value & $6,49 * * *$ & $7,95 * * *$ \\
\hline Degrees of freedom & $(4,152)$ & $(5,151)$ \\
\hline Change in $\mathrm{R}^{2}$ & / & $0,06 * *$ \\
\hline
\end{tabular}

*Statistically significant $p \leq 0,05 ; * *$ Statistically significant $p \leq 0,01 ; * * *$ Statistically significant $p \leq 0,001$

The results in Table 5 show that job satisfaction is a predictor of affective organisational commitment (Bêta = $0,25, p<, 01)$. The addition of job satisfaction in step 2 increases the explanatory power of the model (the change in $\mathrm{R}^{2}$ is $\left.0,06, p<, 01\right)$, suggesting that job satisfaction indeed adds to the explanation of affective organisational commitment.

A final regression analysis was performed with affective organisational commitment as dependent variable and the 
background characteristics (control variables), job insecurity and job satisfaction as predictors (test of the third and last step of Baron and Kenny's procedure). Table 6 contains the results of this last set of regression analyses.

Table 6: Results of a regression analysis with affective organisational commitment as dependent variable, and background characteristics, job satisfaction and job insecurity as predictors (Bêta-coefficients).

\begin{tabular}{|c|c|c|c|}
\hline Predictors & & & \\
\hline Gender & $-0,05$ & $-0,04$ & $-0,03$ \\
\hline Race & $-0,16$ & $-0,17^{*}$ & $-0,18^{*}$ \\
\hline Age & $0,29 * * *$ & $0,28 * *$ & $0,25 * *$ \\
\hline Professional category & $-0,39 * * *$ & $-0,32 * *$ & $-0,35 * * *$ \\
\hline Job Insecurity & / & $-0,18^{*}$ & $-0,13$ \\
\hline Job Satisfaction & l & l & $0,24 * *$ \\
\hline $\mathrm{R}$ & 0,37 & 0,40 & 0,46 \\
\hline $\mathrm{R}^{2}$ & 0,14 & 0,16 & 0,22 \\
\hline F-value & $6,00 * * *$ & $5,90 * * *$ & $6,83 * * *$ \\
\hline Degrees of freedom & $(4,151)$ & $(5,150)$ & $(6,149)$ \\
\hline Change in $\mathrm{R}^{2}$ & 1 & $0,03 *$ & $0,05 * *$ \\
\hline
\end{tabular}

*Statistically significant $p \leq 0.05$; **Statistically significant $p \leq$

$0.01 ; * * *$ Statistically significant $p \leq 0.001$

In order to increase the comparability of the results, Table 6 also contains the first two steps of the stepwise regression (these results are similar to the results in Table 4) ${ }^{1}$. The results in table 6 show that the introduction of job satisfaction in the analysis reduces the impact of job insecurity (Bêta drops from $-0,18(p<0,05)$ in step 2 to 0,13 (n.s.) in step 3). Job satisfaction, however, remains a significant predictor in this last analysis (Bêta $=0,24, p<$ 0,01). According to Baron and Kenny (1986), one can speak of full mediation in this case. Hypothesis 3 is thus corroborated: job satisfaction mediates that association between job insecurity and affective organisational commitment, as hypothesised.

Hypothesis 3 was formulated in a rather general way, by referring to the total job satisfaction scale. Since this total scale can be split into two dimensions (intrinsic versus extrinsic), one can wonder whether both components mediate the association between job insecurity and affective organisational commitment. A mediation by intrinsic job satisfaction is highly unlikely, however, since job insecurity was not associated with this component (hypothesis 1c was not corroborated, see Table 3). A series of regression analyses (not shown here) indeed shows that it is the extrinsic dimension of job satisfaction that fully mediates the relationship between job insecurity and affective organisational commitment.

\section{Discussion}

This study investigated the associations between job insecurity, job satisfaction and organisational commitment

\footnotetext{
${ }^{1}$ The slight differences in results between this part of Table 6 and Table 4 is due to the fact that the amount of respondents differs slightly between both analyses, due to listwise deletion of missing data. In Table 6, an additional variable is introduced in the analysis (job satisfaction), which slightly reduced the amount of respondents.
}

among maintenance workers in a parastatal. In accordance to the literature on job insecurity, the results of this study showed that job insecurity is associated with reduced job satisfaction and with reduced affective organisational commitment. In analysing our data, two additional assumptions were tested, expanding the knowledge accumulated in previous research. First, our results showed that job insecurity was only associated with extrinsic job satisfaction. No association with intrinsic job satisfaction was found, suggesting that the association of job insecurity with total job satisfaction should be attributed to its association with extrinsic satisfaction only. These findings, preliminary as they however are, suggest a limited impact of job insecurity on job satisfaction: its impact in this study seems to be restricted to satisfaction with extrinsic aspects closely related to steady employment itself, example a fixed term contract. Second, a test of mediation was performed. This test suggests that the impact of job insecurity on affective organisational commitment is mediated by job satisfaction. Job insecurity impairs (extrinsic) job satisfaction, which in turn reduces affective organisational commitment. Longitudinal research is needed to test this causal ordering in the future. The associations reported in this article are rather limited, however. No practically significant relationships were found between the total job insecurity score and the two dependent variables, i.e. job satisfaction and organisational commitment. A statistically significant relationship was found between organisational commitment and job satisfaction, but this relationship did not prove practically significant. Some multiple regression analyses indicated that job insecurity only predicts a limited amount of variance in job satisfaction and affective organisational commitment. Future research should find out whether these findings are due to the restriction of our sample to only one company: a parastatal in the province of Gauteng.

This study had several limitations. One of the biggest limitations is that self-report measures were exclusively relied upon. This causes a particular problem in validation studies that use self-report measures exclusively because at last part of the common variance of the measures has to be attributed to method variance (Schaufeli, Maslach \& Marek, 1993). The use of a cross-sectional study design also represents a limitation, i.e. one of the ability to test causal assumptions regarding job insecurity. Longitudinal data would allow for forming a better understanding of the true nature of job insecurity.

Another limitation is that only affective commitment was used as a construct in this study. There is still a possibility that there are correlations between job insecurity and continuous- and normative commitment. Previous researchers like Lord and Hartley (1998), Paswewark and Strawser (1996) and Wasti (2003) indicated such relationships.

Further analysis of the data in future studies can probably be undertaken with success. Structural equation modelling seems to be a potentially useful contributor to the understanding of the relationships among variables. This is especially true if causality is being investigated. The results of the present study can be seen as making some (although 
small) contribution to the understanding of causation of job insecurity. This may help to make the use of structural equation modelling feasible in future studies.

\section{Managerial implications}

The results of the present study indicate that there is a relationship between job insecurity on the one hand and (extrinsic) job satisfaction and affective organisational commitment on the other. Managers should concentrate on decreasing the level of perceived job insecurity among the members of their staff, as it can result in higher levels of extrinsic job satisfaction and affective organisational commitment. Although it cold be difficult to address their perceived level of job insecurity of employees, open and 'intime' communication can help employees to have a clear picture of the work environment. The importance of these two constructs for the organisation, have been highlighted in the introduction of this article.

Management researchers will perhaps now feel challenged to commence research concerning the antecedents of job insecurity and to develop a causal model of job insecurity.

\section{Conclusions and recommendations}

The central purpose of this study was to assess the relationship between job insecurity, job satisfaction and organisational commitment, and to establish whether job insecurity can predict job satisfaction and organisational commitment. Data was gathered regarding the biographical backgrounds of respondents, as well as their levels of job insecurity, job satisfaction and organisational commitment. A relationship was found between job insecurity and extrinsic job satisfaction, and between job insecurity and affective organisational commitment. Job satisfaction was also found to mediate the relationship between job insecurity and affective organisational commitment.

It is anticipated that this study will contribute to future research and management insight regarding the job insecurity, job satisfaction and organisational commitment experienced by employees. The results of this study indicate that further research is warranted. Further research needs to use larger samples and more different outcome variables, in order to fully assess the impact of job insecurity. Further refinement of some of the scales might also be necessary. It is furthermore recommended that future research use confirmatory factor analysis to assess the goodness-of-fit differences between oblique and orthogonal factor models.

Longitudinal studies are needed in order to increase our understanding of the relationship between job insecurity, job satisfaction and organisational commitment, and of the consequences of these concepts for other outcome variables (such as performance and well-being).

\section{References}

Agho, A.O., Price, J.L., \& Mueller, C.W. 1992. 'Discriminant validity of measures of job satisfaction, positive affectivity and negative affectivity', Journal of Occupational and Organisational Psychology, 65: 185-196.
Allen, N.J. \& Meyer, J.P. 1990. 'The measurement and antecedents of affective, continuance, and normative commitment to the organization', Journal of Occupational Psychology, 63: 1-18.

Allen, N.J. \& Meyer, J.P. 1996. 'Affective, continuance and normative commitment to the organisation: an examination of the construct validity', Journal of Vocational Behavior, 49(43): 252-276.

APA, 2002. Publication manual of the American Psychological Association. 5 $^{\text {th }}$ Edition. Washington, DC.

Ashford, S., Lee. C. \& Bobko, P. 1989. 'Content, causes and consequences of job insecurity: a theory-based measure and substantive test', Academy of Management Journal, 32(4): 803-829.

Babin, B.J. \& Boles, J.S. 1996. 'The effects of perceived co-workers involvement and supervisor support on service provider role stress, performance and job satisfaction', Journal of Retailing, 72(1): 250-266.

Bagraim, J.J. 2003. 'The nature and measurement of multiple commitment foci amongst South African knowledge workers', Management Dynamics: Contemporary Research, 12(2):13-23

Baron, R.M. \& Kenny, D.A. 1986 . 'The moderatormediator variable distinction in social psychological research: Conceptual, strategic, and statistical considerations', Journal of Personality and Social Psychology, 51(6):1173-1182.

Boshoff, C. \& Mels, G. 1995. 'Role stress and job satisfaction: Their supervisory antecedents and their influence on organisational commitment', Journal of Industrial Psychology, 21(1):25-32.

Clark, L.A. \& Watson, D. 1995. 'Constructing validity: Basic issues in objective scale development', Psychological Assessment, 7:309-319.

Cohen, J. 1988. Statistical power analysis for behavioural sciences. $2^{\text {nd }}$ Edition. Hillsdale, N.J: Lawrence Erlbaum \& Associates.

Cook, J.D., Hepworth, S.J., Wall, T.D. \& Warr, P.B. 1981. The experience of work: a compendium and review of 249 measures and their use. London: Academic Press.

Coster, E.A. 1992. 'The perceived quality of working life and job satisfaction', Journal of Industrial Psychology, 18(2): 6-9.

Cranny, C.J., Smith, P.C. \& Stone, E.F. 1992. Job satisfaction: How people feel about their jobs and how it affects their performance. NY: Lexington Books.

Davy, J.A., Kinicki, A.J., \& Scheck, C.L. 1997. 'A test of job insecurity's direct and mediated effects on withdrawal cognitions', Journal of Organizational Behavior, 18:323349. 
Dawis, R.V. 1992. 'Person-environment fit and job satisfaction'. In Cranny, C.J., Smith, P.C. \& Stone, E.F. (Eds.). Job satisfaction: how people feel about their jobs and how it affects their performance. New York: Lexington Books, pp. 69-88.

DeCotiis, T. \& Summers, T. 1987. 'A path analysis of a model of the antecedents and consequences of organizational commitment', Human Relations, 40(7):445470 .

De Witte, H. 1999. 'Job insecurity and psychological wellbeing: Review of the literature and exploration of some unresolved issues', European Journal of Work and Organizational Psychology, 8(2):155-177.

De Witte, H. 2000. 'Arbeidsethos en jobonzekerheid: Meting en gevolgen voor welzijn, tevredenheid en inzet op het werk'. In Bouwen, R., De Witte, K., De Witte, H. \& Taillieu, T. (Eds.). Van groep tot gemeenschap. Leuven: Garant, pp. 1-32.

Dekker, S.W. \& Schaufeli, W.B. 1995. 'The effects of job insecurity on psychological health and withdrawal: A longitudinal study', Australian Psychologist, 30:57-103.

Durham, R., Grube, J. \& Castaneda, M. 1994. 'Organisational commitment, the nity of an integrative definition', Journal of Applied Psychology, 79(3):370-380.

Fletcher, C. \& Williams, R. 1996. 'Performance management, job satisfaction and organisational commitment', British journal of management, 7(2):169179.

Hartley, J., Jacobson, D., Klandermans, B. \& Van Vuuren, T. 1991. Job insecurity: Coping with jobs at risk. London: Sage.

Hellgren, J., \& Sverke, M., \& Isaksson, K. 1999. 'A twodimensional approach to job insecurity: Consequences for employee attitudes and well-being', European Journal of Work and Organizational Psychology, 8(2):179-195.

Hellgren, J. \& Sverke, M. 2003. 'Does job insecurity lead to impaired well-being or vice-versa? Estimation of crosslagged effects using latent variable modeling', Journal of Organisational Behavior, 24(2):215.

Hirschfeld, R.R. 2000. 'Validity studies. Does revising the intrinsic and extrinsic subscales of the Minnesota Satisfaction Questionnaire Short Form make a difference?' Educational Psychological Measurement, 60: 255-270.

Howard, A. 1995. The changing nature of work. San Francisco, CA: Josey-Bass.

Hui, C. \& Lee, C. 2000. 'Moderating effects of organizational-based self-esteem on organizational uncertainty: Employee response relationships', Journal of Management, 26(2):215-232.
Judge, T.A., Bourdreau, J.W. \& Bretz, R.D., Jr. 1994. 'Job satisfaction and attitudes of male executives', Journal of Applied Psychology, 79(5):767-782.

Kampfer, L., Boshoff, A.B. \& Venter, D.J.L 1994. 'The dimensions of employee commitment: A South African confirmatory factor analysis', Journal of Psychology, 20(2): 1-7.

Kets De Vries, M.F.R. \& Balaz, K. 1997. 'The downside of downsizing', Human Relations, 50: 11-50.

Kinnunen, U., Mauno, S., Nätti, J. \& Happonen, M. 2000. 'Organizational antecedents and outcomes of job insecurity: A longitudinal study in three organizations in Finland', Journal of Organizational Behavior, 21: 443-459.

Kirk, R.E. 1996. 'Practical significance: A concept whose time has come', Educational and psychological measurement, 56:746-759.

Lam, T., Baum, T. \& Pine, R. 1998. 'Study of managerial job satisfaction in Hong Kong's Chinese restaurants', International Journal of Contemporary Hospitality Management, 13(1): 1-10.

Li-Ping Tang, T. \& Talpade, M. 1999. 'Sex differences in satisfaction with pay and co-workers', Public Personnel Management, 28(3):345-348.

Locke, E.A. 1976. 'The nature causes and causes of job satisfaction'. In Dunnette, M.C. (Ed.). Handbook of industrial and organisational psychology. Chicago, IL: Rand McNally.

Lok, P. \& Craword, J. 2001. 'Antecedents of organisational commitment and the mediating role of job satisfaction', Journal of Managerial Psychology, 16(8):594-613.

Lord, A. \& Hartley, J. 1998. 'Organizational commitment and job insecurity in a changing public service', European Journal of Work and Organizational Psychology, 7:341354.

Marais, E.N. \& Schepers, J.M. 1996. 'The effects of organisational restructuring on job satisfaction, career aspirations and stress levels of employees', Journal of Industrial Psychology, 22(3):1-6.

Mauno, S. \& Kinnunen, U. 1999. 'Job insecurity and wellbeing: A longitudinal study among male and female employees in Finland', Community, Work \& Family, 2:147171.

Mauno, S. \& Kinnunen, U. 2000. 'The stability of job and family involvement: Applying the multi-wave, multivariable technique to longitudinal data', Work and stress, 14:15-64.

Meyer, J.P. \& Allen, N.J. 1997. Commitment in the workplace: Theory, research and application. Thousand Oaks: Sage. 
Meyer, J.P., Allen, N.J. \& Smith, C. 1993. 'Commitment to organizations and occupations: Extension and test of a threecomponent conceptualization', Journal of Applied Psychology, 87(84):538-551.

Michaels, P. 1994. 'An expanded conceptual framework on organisational commitment and job satisfaction for sales force management', Journal of Business and Society, 7(1):42-67.

Mohr, G.B. 2000. 'The changing significance of different stressors after the announcement of bankruptcy: A longitudinal investigation with special emphasis on job insecurity', Journal of Organizational Behavior, 21:337359.

Mohren, D.L., Swaen, G.M.H., Van Amelsvoort, L.G.P.M., Borm, P.J.A. \& Galama, J.M.D. 2003. 'Job insecurity as a risk factor for common infections and health complaints', Journal of Occupational and Environmental Medicine, 45(2):123.

Morrison, E.W. 1994. 'Role definitions and organizational employee's perspective', Academy of Management Journal, 37(6):543-1567.

Mowday, R.T., Porter, L.W., \& Steers, R.M. 1982. Organisational linkage: The psychology of commitment, absenteeism and turnover. New York, NY: Academic Press.

Mowday, R.T., Porter, L.W. \& Steers, R.M. 1979. 'The measurement of organizational commitment', Journal of Vocational Behavior, 14:224-247.

Näswall, K. \& De Witte, H. 2003. 'Who feels insecure in Europe? Predicting job insecurity from background variables', Economic and Industrial Democracy, 24(2): 189215.

Nunnally, J.C., \& Bernstein, I.H. 1994. Psychometric theory $3^{\text {rd }}$ Edition.. New York: McGraw-Hill.

O’Reilly, C. \& Chatman, J. 1986. 'Organisational commitment and psychological attachment: The effects of compliance, identification and internalisation on pro-social behaviour', Journal of Applied Psychology, 71(3):492-499.

Pasewark, W.R. \& Strawser, J.R. 1996. 'The determinants and outcomes associated with job insecurity in a professional accounting environment', Behavioral Research in Accounting, 8:91-110.

Pretorius, T.B. 1993. 'Commitment, participation indecision-making and social support: Direct and moderating effects on the stress-burnout relationship within an educational setting', South African Journal of Psychology, 23(1):10-14.

Preuss, G.L. \& Lautsch, B.A. 2003. 'The effect of formal versus informal job security on employee involvement programs’, Industrial Relations, 57(3):517-539.
Price, J. \& Muller, C. 1981. Professional turnover: The case of nurses. New York: Medical and Scientific Books.

Probst, T.M. 2000. 'Wedded to the job: Moderating effects of job involvement on the consequences of job insecurity', Journal of Occupational Health Psychology, 5:63-73.

Probst, T.M. \& Brubaker, T.L. 2001. 'The effects of job insecurity on employee safety outcomes: Cross-sectional and longitudinal explorations', Journal of Occupational Health Psychology, 6(2):139-158.

Q'Quin, K. 1998. 'Job satisfaction and intentions to turnover in human services agencies perceived as stable or non-stable’, Perceptual \& Motor Skills, 88(1):339-344.

Roberts, H.F. \& Roseanne, F.J. 1998. 'Evaluating the interaction between self-leadership and work structure in predicting job satisfaction', Journal of Business Psychology, 12:257-267.

Rosenblatt, Z. \& Ruvio, A. 1996. 'A test of a multidimensional model of job insecurity: The case of Israeli teachers', Journal of Occupational Behavior, 17:587605.

Rosenblatt, Z., Talmud, I. \& Ruvio, A. 1999. 'A genderbased framework of the experience of job insecurity and its effects on work attitudes', European Journal of Work and Organizational Psychology, 8(2):197-217.

Russ, F. \& McNeilly, K. 1993. Links among satisfaction, commitment and turnover intention: The moderating effect of experience, gender and performance', Journal of Business Research, 34:57-65.

SAS Institute. 2000. The SAS System for Windows: Release 8.01. Cary, NC: SAS Institute Inc.

Schaufeli, W.B., Maslach, C. \& Marek (Eds.). 1993. Professional burnout: Recent developments theory and research. Washington, DC: Taylor \& Francis.

Schneider, B. \& Snyder, R.A. 1975. 'Some relations between job satisfaction and organisational climate', Journal of Applied Psychology, 60(3):318-328.

Sempane, M.E., Rieger, H.S. \& Roodt, G. 2002. 'Job satisfaction in relation to organisational culture', Journal of Industrial Psychology, 28(2):23-30.

Shaughnessy, J.J. \& Zechmeister, E.B. 1997. Research methods in psychology. $4^{\text {th }}$ Edition. New York: McGrawHill.

Somers, M.J. 1993. 'A test of the relationship between affective and continuance commitment using non-recursive models', Journal of Occupational and Organizational Psychology, 66(2):185-192.

Spector, P. 1997. Job satisfaction: Application, assessment, causes, and consequences. London: Sage. 
Steyn, H.S. 2002. 'Practical significant relationships between two variables', South African Journal of Industrial Psychology, 28(3):10-15.

Suliman, A.M. \& Iles, P.A. 2000. 'The multi-dimensional nature of organizational commitment in a non-western context', Journal of Managerial Psychology, 19(1):1-7.

Sverke, M. \& Hellgren, J. 2002. 'The nature of job insecurity: Understanding employment uncertainty on the brink of a new millennium', Applied Psychology: An international Review, 51(1): 23-42.

Sverke, M., Hellgren, J., Näswall, K. \& Chirumbolo, A., De Witte, H., \& Goslinga, S. 2004. Job insecurity and union membership: European unions in the wake of flexible production. Bruxelles: P.I.E.-Peter Lang.

Tabachnick, B. G. \& Fidell, L. S. 2001. Using multivariate statistics. $4^{\text {th }}$ Edition. Boston, MA: Allyn \& Bacon.

Van Vuuren, T. 1990. Met ontslag bedreigd. Werknemers in onzekerheid over hun arbeidsplaats bij veranderingen in de organisatie. Amsterdam: VU Uitgeverij.

Visser, P.J., Breed, M. \& Van Breda, R.1997. 'Employee satisfaction: A triangular approach', Journal of Industrial Psychology, 23(2):19-24.

Wasti, S. A. 2003. 'The influence of cultural values on antecedents of organisational commitment: An individuallevel analysis', Applied psychology: An International Review, 52:533-554.

Weiss, D.J., Dawis, R.V., England, G.W. \& Lofquist, LH. 1967. Manual for the Minnesota Satisfaction Questionnaire. MN: University of Minnesota.

Yousef, D.A. 1997. 'Satisfaction with job security as a predictor of organisational commitment and job performance in a multicultural environment', International Journal of Manpower, 19(3):1-8.

Yousef, D.A. 2000. 'Organisational commitment and job satisfaction as predictors of attitudes toward organizational change in a non-western setting', Personnel Review, 29(5):557-592. 
